American Journal of Applied Sciences 6 (6): 1212-1216, 2009

ISSN 1546-9239

(C) 2009 Science Publications

\title{
Influence of Hillside Gradient on Forest Road Cross Section Components in a Loamy Clay Soil
}

\author{
${ }^{1}$ Aidin Parsakhoo, ${ }^{2}$ Seyed Ataollah Hosseini, ${ }^{2}$ Majid Lotfalian and ${ }^{2}$ Hamid jalilvand \\ ${ }^{1}$ Faculty of Natural Resources, Mazandaran University, Iran \\ ${ }^{2}$ Department of Forestry, Faculty of Natural Resources, Mazandaran University, Iran
}

\begin{abstract}
Problem statement: In this study to evaluate the effects of hillside gradient on forest road cross section components in a loamy clay soil the amount of cut and fill slopes gradient and length, road bed and earthwork width were taken on tangent sections in a lat talar forest roads of Iran. Approach: The objective of this study were: (i) to evaluate the direct effects of hillside gradient on cross section components such as cut and fill slopes, road bed and earthwork width in a loamy clay soil, (ii) to use the model to predict the effect of hillside gradient on cross section components. Results: Results indicated that the regression analysis between hillside gradient and cut slope length had a significant linear relationship $(p<0.0001)$, with equation of $Y=0.046+0.054 X\left(R^{2}=0.60\right)$. The equation for the calculation of earthwork width $(\mathrm{Y})$ from hillside gradient was $\mathrm{Y}=4.928+0.132 \mathrm{X}\left(\mathrm{R}^{2}\right.$ $=0.44)$. A significant linear relationship $(p<0.0001)$, with equation of $Y=0.144 \times-2.638\left(R^{2}=0.64\right)$ was found between hillside gradient and fill slope length values. Conclusion: Through analysis of variance it was also found that the hillside gradient had a significant influence $(\mathrm{p}<0.0001)$ on the cross section components.
\end{abstract}

Key words: Hillside gradient, cross-section, forest road, loamy clay, regression analysis

\section{INTRODUCTION}

The construction of forest roads for the Iranian forests to facilitate timber harvest and attainment of other multiple use objectives requires a high capital investment. A mistake in planning a road, such as ignoring the effects of environmental and other parameters, leads not only to the waste of public investment, but also to adverse environmental impacts and increase maintenance costs ${ }^{[7,8]}$.

During the construction phase of a forest road project, the planning and design decisions that were made earlier are carried out on the ground to achieve the desired road standard in a way that is efficient and effective and results in minimal impact to the environment ${ }^{[15]}$. On the other hand, forest roads are at risk of road surface erosion and are subject to cut-andfill slope failures. Therefore, it is important to design forest roads by considering not only cost efficiency but also the appropriate management of water and soil ${ }^{[3,10]}$.

Cross-sections are the natural ground profile perpendicular to the road. They show the slope and angle of topography at any given point. Common to most cross-sections are the cut and fill sections of the road, where the cut is the portion of the uphill bank that is removed and the fill is where material has been added to and compacted on the downhill side of the road.
Road sections are considered balanced when the volume of earth cut equals the volume of compacted fill. Earth working width is total horizontal width of land affected by the construction of the road, from the top of the cut slope to the base of the fill slope. Also, the road bed is the width of road which consists of ditch, shoulders and travel way ${ }^{[12,14,16]}$.

A number of studies have been conducted to analyze the effect of hillside gradient on cross section components. Gorton ${ }^{[6]}$ in his study in Germany forests found that the length of the fill slope was about 3.5, 12 and $22 \mathrm{~m}$ for hillside gradients of 45, 60 and $70 \%$. Also, an angle of repose for side cast material was about $37^{\circ}$ and on slopes of over $75 \%$ a fill cannot be established at all. Fill slope plays an important role on overall aesthetic value of road templates ${ }^{[1]}$. The mean cut-slope heights for gradient classes of $0-15,15-30,30-60$ and over $60 \%$ were estimated as $0.75,1.5,3.0$ and $7.5 \mathrm{~m}$, respectively. Therefore, the forest lands with steep hillside gradient deliver more sediment yield to the streams than a forest land with an even hillside gradient $^{[2]}$

The objective of this study were: (i) to evaluate the direct effects of hillside gradient on cross section components such as cut and fill slopes, road bed and earthwork width in a loamy clay soil, (ii) to use the model to predict the effect of hillside gradient on cross

Corresponding Author: Aidin Parsakhoo, Department of Forestry, Faculty of Natural Resources, Mazandaran University, P.O. Box: 737, Badeleh, Sari City, Mazandaran Province, IR-Iran 
section components. A better understanding of the effects of hillside gradient on forest road cross sections, product recovery and financial return will help improve forest road construction practices based on management goals.

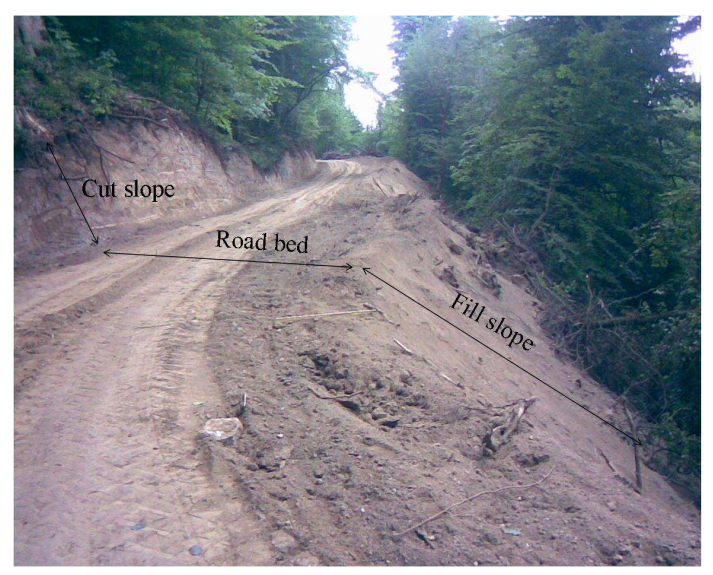

Fig. 1: Components of the forest road cross section

Table 1: Determining the fill slope gradient with the method of Indian Roads Congress (I.R.C

\begin{tabular}{lcccc}
\hline $\begin{array}{l}\text { Fill slope length } \\
(\mathrm{m})\end{array}$ & 1.5 & 3 & 4.5 & 6 \\
\hline $\begin{array}{l}\text { Fill slope gradient } \\
\text { (Degree) }\end{array}$ & 14 & 18 & 22 & 27 \\
\hline
\end{tabular}

Table 2: Determining the cut slope gradient with the method of Indian Roads Congress (I.R.C)

\begin{tabular}{lllll}
\hline Soil type & $\begin{array}{l}\text { Common } \\
\text { Soil }\end{array}$ & Conglomerate & $\begin{array}{l}\text { Soft } \\
\text { stone }\end{array}$ & $\begin{array}{l}\text { Hard } \\
\text { stone }\end{array}$ \\
\hline $\begin{array}{l}\text { Cut slope } \\
\text { gradient } \\
\text { (Degree) }\end{array}$ & $39-45$ & $35-39$ & $29-35$ & Vertical \\
\hline
\end{tabular}

\section{MATERIALS AND METHODS}

Data were collected in the spring of 2008 at the Lat Talar site of northern forest of Iran $\left(36^{\circ} 12^{\prime} 55^{\prime \prime}\right.$ to $36^{\circ}$ $15^{\prime} 45^{\prime \prime} \mathrm{N}, 53^{\circ} 9^{\prime} 40^{\prime \prime}$ to $53^{\circ} 13^{\prime} 55^{\prime \prime} \mathrm{E}$ and elevation $1000 \mathrm{~m})$. Loamy clay soil contains sand, silt and clay, in such well-balanced proportions that none produces a dominating influence. It is porous, which allows for good air circulation and retention of moisture. The study area has a mid moist and cold climate and its bedrock is typically marl, marl lime and limestone. The soil depth is greater than $0.45 \mathrm{~m}$, with a rooting depth of $0.6 \mathrm{~m}$.

Roads in Lat Talar were not paved and their density was $10 \mathrm{~m} \mathrm{ha}^{-1}$ Fig. 1. Forest roads must be constructed according to guide lines which have published by the scientific and operational organizations such as Indian Roads Congress ${ }^{[\rho]}$ (Table 1 and 2), Institute of B.C.E.O.M ${ }^{[1]}$ (Table 3) and Plane and Budget Organization of Iran ${ }^{[17]}$ (Table 4).
Data collection: To be able to determine the amount of road bed, earthwork width, cut and fill slopes gradient and length, the cross sectional constructed road profiles after every $20 \mathrm{~m}$ (on tangent sections) were taken by

Table 3: Determining the cut or fill slope gradient with the method of B.C.E.O.M Institute

\begin{tabular}{llll}
\hline $\begin{array}{l}\text { Cut or fill } \\
\text { Slope }\end{array}$ & Cut or fill slope gradient (Degree) & \\
length $(\mathrm{m})$ & Flat or hilly & Moderate slope & Steep slope \\
\hline $0-1.5$ & 9 & 14 & 14 \\
$1.5-3$ & 14 & 18 & 27 \\
$3-4.5$ & 18 & 22 & 30 \\
$4.5-6$ & 27 & 27 & 34 \\
More than 6 & 27 & 18 & 34 \\
\hline
\end{tabular}

Table 4: Determining the cut slope gradient with the method of Plane and Budget Organization of Iran

\begin{tabular}{llllll}
\hline Soil type & $\begin{array}{l}\text { Soft } \\
\text { Sand }\end{array}$ & $\begin{array}{l}\text { Silt } \\
\text { sand }\end{array}$ & $\begin{array}{l}\text { Dense } \\
\text { gravel }\end{array}$ & Silt clay & Spall \\
\hline $\begin{array}{l}\text { Cut slope } \\
\text { gradient (degree) }\end{array}$ & $27-31$ & $31-35$ & $39-45$ & $34-45$ & $39-45$ \\
\hline
\end{tabular}

means of the meter and inclinometer. Totally, the components of 120 cross sections were measured. In other word, 30 cross sections were taken for each of the slope classes of 30-40, 40-50, 50-60 and 60-70.

Statistical analysis: The relationships between hillside gradient and the cross section components were investigated by linear regression procedures using the SAS statistical software. Analysis of variance (ANOVA) was used to determine the effects of hillside gradient on forest road cross section components. Wherever treatment effects were significant the SNK test at probability level of $5 \%$ was carried out to compare the means.

\section{RESULTS AND DISSCUTION}

A well designed and constructed forest road cross section is prerequisite to multiple use forest management activities in forest. The roadway or area of exposed soil of a newly constructed road consists of three distinct surfaces with different characteristics that affect their erodibility. These surfaces are the cut slope, the roadbed and the fill slope $\mathrm{e}^{[2,5,13]}$.

Table 5 indicates that the regression analysis between hillside gradient and cut slope length had a significant linear relationship $(\mathrm{p}<0.0001)$, with equation of $Y=0.046+0.054 X\left(R^{2}=0.60\right)$. The equation for the calculation of earthwork width $(\mathrm{Y})$ of forest roads from hillside gradient was $\mathrm{Y}=4.928+0.132 \mathrm{X}\left(\mathrm{R}^{2}=0.44\right)$. A significant linear relationship $(\mathrm{p}<0.0001)$, with equation of $\mathrm{Y}=0.144 \mathrm{X}-2.638\left(\mathrm{R}^{2}=0.64\right)$ was found between hillside gradient and fill slope length values.

Through analysis of variance it was also found that the hillside gradient had a significant influence $(p<0.0001)$ on the cross section components.

The amount of cuts and fills length describes the volume of earthworks. According to this factor the 
Am. J. Applied Sci., 6 (6): 1212-1216, 2009

Table 5: The summary of the regression analysis

\begin{tabular}{|c|c|c|c|c|c|c|}
\hline $\mathrm{R}^{2}$ & $\mathrm{~F}$ & $\mathrm{P}$ & SE & Parameter. E & Variable & Cross section \\
\hline \multirow[t]{2}{*}{0.60} & $150.750^{* * *}$ & $<0.0001$ & 0.223 & 0.046 & Intercept & Cut slope length \\
\hline & & $<0.0001$ & 0.004 & 0.054 & Slope & \\
\hline \multirow[t]{2}{*}{0.06} & $7.26^{* *}$ & $<0.0001$ & 2.226 & 48.862 & Intercept & Cut slope gradient \\
\hline & & 0.0081 & 0.043 & 0.116 & Slope & \\
\hline \multirow[t]{2}{*}{0.12} & $22.840^{* * *}$ & $<0.0001$ & 0.294 & 7.469 & Intercept & Road bed \\
\hline & & $<0.0001$ & 0.005 & -0.027 & Slope & \\
\hline \multirow[t]{2}{*}{0.44} & $87.41^{* * *}$ & $<0.0001$ & 0.728 & 4.928 & Intercept & Earthwork width \\
\hline & & $<0.0001$ & 0.014 & 0.132 & Slope & \\
\hline \multirow[t]{2}{*}{0.11} & $15.10^{* * *}$ & $<0.0001$ & 1.165 & 29.537 & Intercept & Fill slope gradient \\
\hline & & 0.0002 & 0.022 & 0.088 & Slope & \\
\hline \multirow[t]{2}{*}{0.64} & $196.430^{* * *}$ & $<.0001$ & 0.526 & -2.638 & Intercept & Fill slope length \\
\hline & & $<.0001$ & 0.010 & 0.144 & Slope & \\
\hline
\end{tabular}
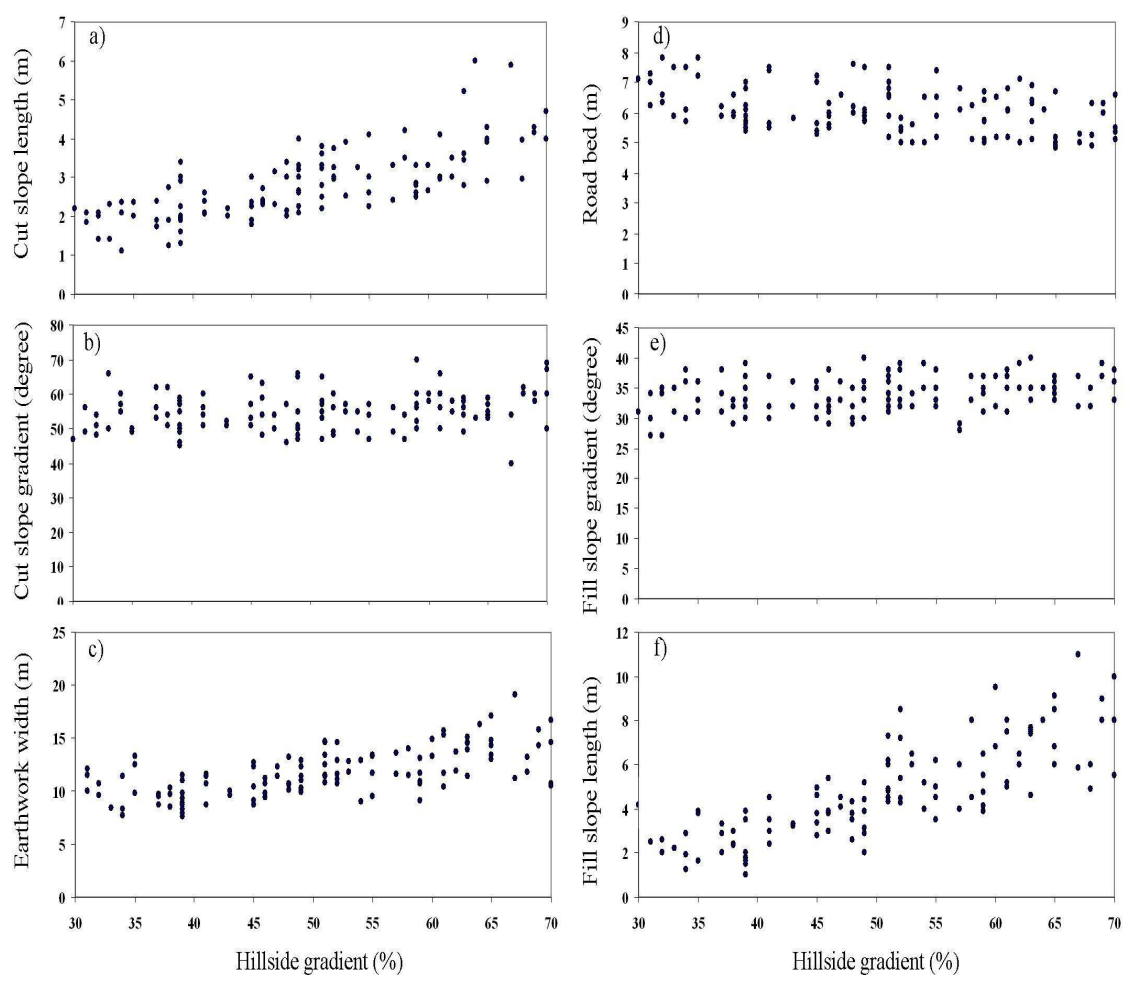

Fig. 2: Relationship between the components of forest road cross section and hillside gradient

Table 6: Comparison of mean cross section components in different slope classes

\begin{tabular}{lllll}
\hline & \multicolumn{4}{c}{ Hillside classes (\%) } \\
& ------------ \\
Cross-section & $30-40$ & $40-50$ & $50-60$ & $60-70$ \\
\hline Cut slope length (m) & $2.13^{\mathrm{d}}$ & $2.54^{\mathrm{c}}$ & $2.99^{\mathrm{b}}$ & $3.73^{\mathrm{a}}$ \\
Cut slope gradient (degree) & $53.53^{\mathrm{b}}$ & $54.47^{\mathrm{ab}}$ & $54.70^{\mathrm{ab}}$ & $57.07^{\mathrm{a}}$ \\
Earthwork width (m) & $10.09^{\mathrm{d}}$ & $10.78^{\mathrm{c}}$ & $12.04^{\mathrm{b}}$ & $13.78^{\mathrm{a}}$ \\
Road bed (m) & $6.49^{\mathrm{a}}$ & $6.18^{\mathrm{b}}$ & $5.96^{\mathrm{cb}}$ & $5.76^{\mathrm{c}}$ \\
Fill slope gradient (degree) & $33.20^{\mathrm{b}}$ & $33.00^{\mathrm{b}}$ & $34.37^{\mathrm{ab}}$ & $35.40^{\mathrm{a}}$ \\
Fill slope length (m) & $2.77^{\mathrm{d}}$ & $3.72^{\mathrm{c}}$ & $5.32^{\mathrm{b}}$ & $7.31^{\mathrm{a}}$ \\
\hline
\end{tabular}

designer can suggest impacts on the environment. The area, size, slope inclination and the way of slope protection can contribute to the minimization of negative impacts, however this would be only a repressive measure. The vertical cut method speeds construction, reduces costs and eliminates the need for back sloping and fill compaction ${ }^{[8,11]}$. The difference in means of cut slope length between different slopes classes was significant (Table 6). As cut slopes length increased with increasing hillside gradient due to more excavation in steeper slopes for establishing the road bed on natural ground (Fig. 2a).

Cut slope gradient in slope class of $60-70 \%$ was more than the slope class of $30-40 \%$ (Table 6). Generally, with increasing hillside gradient, the cut slope gradient not changed due to soil tendency to 

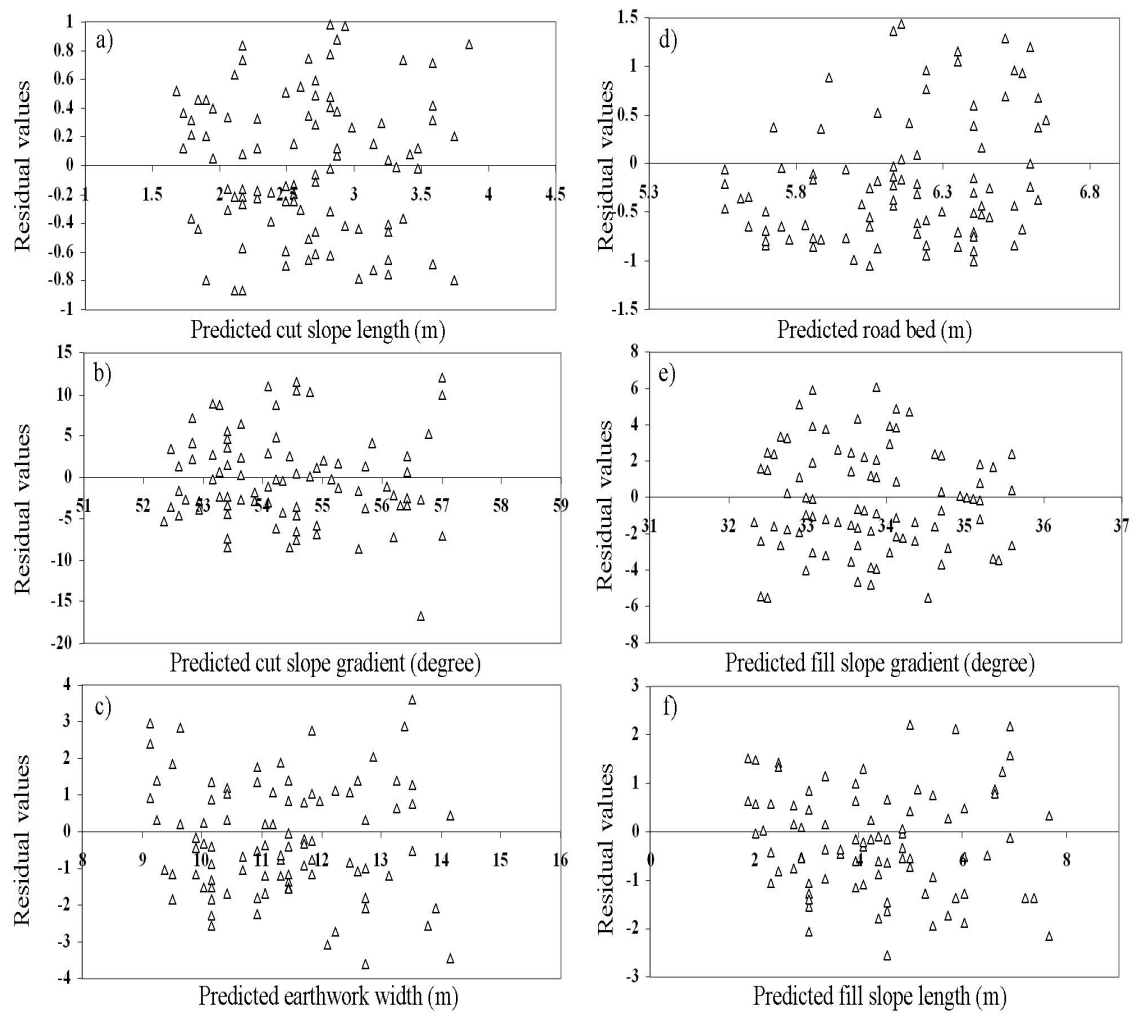

Fig. 3: Distribution of residual versus predicted values for model verification

natural angle (Fig. 2b). By increasing the cut and fill slopes length the earthwork width was significantly influenced (Table 6). Earthwork width increased with increasing the hillside gradient (Fig. 2c). Road bed width decreased with increasing hillside gradient $(\mathrm{p}<0.05)$ because of soil instability in steeper slopes (Table 6, Fig. 2d).

Soil tendency to natural angle caused the fill slope gradient be approximately even in different slope classes (Table 6, Fig. 2e). There was significant difference $(\mathrm{p}<0.05)$ between means of fills slope length in different slope classes (Table 6). Fill slope length in steeper slopes was significantly more than lower slope classes; particularly near the flat floor (Fig. 2f). This result was in agreement with Gorton ${ }^{[6]}$ studies. He found that the length of the fill slope was about $3.5,12$ and $22 \mathrm{~m}$ for hillside gradients of 45,60 and $70 \%$. Also, an angle of repose for side cast material was about $37^{\circ}$ and on slopes of over $75 \%$ a fill cannot be established at all.

The models for cut slope length, earthwork width and fill slope length confirmed after the verifying (Fig. 3).

\section{CONCLUSION}

The results from this study revealed that the forest roads cut and fill slopes length and earthwork width highly depend on hillside gradient. Even though hillside gradient effects on cross section components vary based on the cross section types ( just filling or cutting), the most important attributes to consider in predicting earthwork width, cut and fill slope length are hillside gradient and soil texture. Increasing the cut and fill slope length increases the amount of environmental damages and sediment yield from cut and fill slopes area to ditch through soil creep, sheet wash and slumping. The accuracy of these results still needs to be validated in a field study. Therefore, this methodology can be used as a decision support tool in predicting some of the cross sections components and identifying the problematic road segments with high sediment yield potential.

To prepare a road embankment, removal and placement of earth to construct a road embankment can generate serious environmental impacts on ground water, increase soil erosion, impair drainage and increase the risk of flooding and landslide. To avoid 
these problems, the contractor should undertake the following measures:

- Balance as much as possible cuts and fills to reduce the amount of unused materials

- In steep terrain or mountainous areas, the excess materials from cuts should not be pushed to the edge of the road or disposed in the down slope of the roads

- Provide immediately slope stabilization in the form of concrete wall, rock fill, vegetative slope protection, or combined methods in any road embankment with upper and down slope steeper than $30 \%$

- Where the ground water level is relatively shallow, excavation should be done carefully to avoid cutting aquifers that could disturb the supply of water to nearby wells and should not obstruct natural drainage pattern

\section{ACKNOWLEDGEMENTS}

The authors are grateful to Nazanin Parsakhoo who typed numerous versions of this paper with considerable technical expertise. The authors would also like to thank two anonymous referees for their constructive comments on an earlier version of this study. The work of the authors was supported in part by the faculty of natural resources.

\section{REFERENCES}

1. Akay, A.E., M. Pak, N. Yenilmez and H. Demirbag, 2007. Aesthetic Evaluations of Forest Road Templates. Int. J. Nat. Eng. Sci., 1: 65-68.

2. Akay, A.E., O. Erdas, R. Mahmut and A. Yuksel, 2008. Estimating sediment yield from a forest road network by using a sediment prediction model and GIS techniques. Build. Environ., 43: 687-695.

3. Aruga, K., J. Sessions and A.E. Akay, 2005. Heuristic planning techniques applied to forest road profiles. J. For. Res., 10: 83-92.

4. BCEOM Societe Francaiso D'Ingenieri. 2005. Completion Report for Consulting Services for the Implementation of the Long- term PerformanceBased Maintenance Project. Manila.

5. Demir, M. and T. Ozturk, 2004. A research on forest road planning and projecting by inroads software in bolu region of Turkey. Am. J. Applied Sci., 1: 295-301.
6. Gorton, F., 1985. Praxis und kosten einer landschaftsschonenden bauausführung von forststrassen. Allgemeine Forstzeitung, Wien., 96: 241-244.

7. Heidari, H., 1980. Proposed forest road policies and procedures for the Iranian Forests. Colorado State University. Forest and wood Sciences Department. PhD Thesis, pp: 45-78.

8. Heralt, L., 2002. Using the ROADENG system to design an optimum forest road variant aimed at the minimization of negative impacts on the natural environment. J. For. Sci., 48: 361-365.

9. Indian Roads Congress (IRC)., 2007. Roads, Transport Planning, Traffic Assessment and Policies.

10. Jamaludin, S., B.K. Huat and O. Husaini, 2006. Evaluation of slope assessment systems for predicting landslides of cut slopes in granitic and meta-sediment formations. Am. J. Environ. Sci., 2: 135-141.

11. Lloyd, W. and J. Swift, 1984. Soil losses from roadbeds and cut and fill slopes in the southern appalachian mountains. South. J. Appl. For., 8: 209-215.

12. Luce, C.H. and T.A. Black, 1999. Sediment production from forest roads in western Oregon. Water Resour Res., 5: 61-70.

13. Lugo, A.E. and H. Gucinski, 2000. Function, effects and management of forest roads. For. Ecol. Manage., 133: 249-262.

14. Mobarak Khamis, S., 2001. Assessment of different methods for design, construct and maintenance of low cost roads in under developed countries. MS.c Thesis, pp: 95-107.

15. Parsakhoo, A., S.A. Hosseini, H. Jalilvand and M. Lotfalian, 2008. Physical soil properties and slope treatments effects on hydraulic excavator productivity for forest road construction. Pak. J. Bio. Sci., 11: 1422-1428.

16. Ryan, T., H. Phillips, J. Ramsay and J. Dempsey, 2004. Forest Road Manual, Guidelines of the Design, Construction and Management of Forest Road, National Council for Forest Research and Development, pp: 116-136.

17. Sarikhani, N. and B. Majnonian, 1994. Forest roads plan, performance and utilization guide line. Published by Program and Budget Organization of Iran (PBOI)., 131: 175 